\title{
The Framework Convention for the Protection of National Minorities and the Northern Ireland Bill of Rights process

\author{
Elizabeth Craig* \\ University of Sussex
}

\begin{abstract}
$\mathrm{I}^{\mathrm{s}-\mathrm{s}}$ was privileged to work as a research assistant with Tom Hadden in the late 1990s on a project exploring how issues of integration and separation were being addressed both internationally and in other divided societies. ${ }^{1}$ At that time it appeared that the idea of Bill of Rights for Northern Ireland would soon become a reality. The Belfast Agreement of 1998 had of course envisaged that the Northern Ireland Human Rights Commission (NIHRC) would

consult and advise on the scope for defining in Westminster legislation, rights supplementary to those in the European Convention on Human Rights, to reflect the particular circumstances of Northern Ireland, drawing as appropriate on international instruments and experience. ${ }^{2}$
\end{abstract}

The project therefore appeared especially timely and focused in particular on rights guarantees in developing international standards such as the Organization for Security and Co-operation in Europe's (OSCE) Copenhagen Document of $1990,{ }^{3}$ the UN Declaration on the Rights of Persons Belonging to National or Ethnic, Religious and Linguistic Minorities 1992, and the Council of Europe's Framework Convention for the Protection of National Minorities 1995. It was clear that these instruments contained principles and goals that were particularly relevant to the developing peace process in Northern Ireland, but their limitations have also come to the fore during the course of the last decade. The Framework Convention has been the focus of particular attention in Northern Ireland and this article examines the unique role that this instrument has played in the Bill of Rights process so far, focusing in particular on the drawbacks of placing too heavy a reliance on the Framework Convention as an instrument that can be easily "incorporated" into domestic law.

\footnotetext{
* PhD, Lecturer in Law, University of Sussex. The author also worked as legal adviser to the Culture, Identity and Language Working Group of the Northern Ireland Bill of Rights Forum from October 2007 to March 2008.

$1 \mathrm{~T}$ Hadden and E Craig, Integration and Separation: Rights in divided societies (Belfast: Fortnight Educational Trust 2000).

2 Strand 3: Rights, Safeguards and Equality of Opportunity, Human Rights, para. 4 (10 April 1998).

3 Document of the Copenhagen Meeting of the Conference on the Human Dimension of the CSCE, 29 June 1990 (hereafter Copenhagen Document).
} 


\section{The Framework Convention and its relationship to other minority rights instruments}

The Conference on Security and Co-operation in Europe (CSCE), now the OSCE, took the initiative in relation to the development of new minority rights norms following the end of the Cold War, including a specific section (s. IV) on questions relating to national minorities in the Copenhagen Document adopted on 29 June 1990. Its contents were reportedly agreed in a mood of "euphoria and optimism" before the minority rights agenda was overshadowed by developments in Yugoslavia and other areas of central and eastern Europe. ${ }^{4}$ The UN General Assembly followed with the adoption of a soft-law Declaration on the Rights of Persons Belonging to National or Ethnic, Religious and Linguistic Minorities in 1992.5 It then fell to the Council of Europe to transform "to the greatest possible extent" the political commitments in the Copenhagen Document into legally binding obligations. ${ }^{6}$ This transformation process resulted in a weakening of many of the substantive provisions. For example, only the Copenhagen Document refers to the establishment of autonomous administrations as a means of protecting and creating conditions for the promotion of minority identity whereas the other two instruments limit their focus in this area to guarantees of effective participation in decision-making processes. ${ }^{7}$ Nevertheless, the similarities between the three instruments remain striking, with considerable overlap in the substantive issues addressed.

Of the three instruments it was only the Framework Convention that was intended to impose legally binding obligations on states. It was therefore perhaps fairly unsurprising that it became the main focus of attention in discussions over the content of provisions addressing culture, identity and language issues in a future Bill of Rights for Northern Ireland. However, the Framework Convention had other unique characteristics. It was, for example, the only instrument to confer a specific right to choose to be treated or not to be treated as belonging to a national minority. ${ }^{8}$ Tom Hadden's support for the inclusion of a right to self-identification in a Bill of Rights for Northern Ireland is well known and it is not my intention to revisit some of the controversy over its proposed inclusion here. ${ }^{?}$ Whilst I would concur with the views of three Council of Europe experts that such a provision should not be included if there is no "broad societal consensus" on the issue, ${ }^{10}$ criticisms of "forum shopping" on the part of the NIHRC in relation to this and other controversial issues appear rather harsh. ${ }^{11}$ This is particularly so given that the Framework Convention only came into force in 1998, with the first Opinions on State reports adopted

4 S Roth, "Comments on the CSCE meeting of experts on national minorities and its concluding document" (1991) 12 Human Rights Law Journal 330, at 331.

5 UN GA Res. 47/135 of 18 December 1992.

6 "Vienna Declaration of the Heads of State and Government of the Member States of the Council of Europe on the Reform of the Control Mechanism of the ECHR, on National Minorities, and on a Plan of Action against Racism, 9 October 1993" (1993) 14 Human Rights Law Journal 373, at 375.

7 Cf. para. 35 of the Copenhagen Document, n. 3 above, with Article 2 of the Minorities' Declaration and Article 15 of the Framework Convention.

8 Article 3 reads: "Every person belonging to a national minority shall have the right freely to choose to be treated or not to be treated as such and no disadvantage shall result from this choice or from the exercise of the rights which are connected to that choice." Cf. para. 32 of the Copenhagen Document, n. 3 above.

9 C McCrudden, "Consociationalism, equality and minorities in the Northern Ireland Bill of Rights debate: the role of the OSCE High Commissioner on National Minorities" in J Morison, K McEvoy and G Anthony (eds), Judges, Transition and Human Rights (Oxford: Oxford University Press 2007), pp. 315, pp. 337-54.

10 Council of Europe Experts, "Comments on certain aspects of a Bill of Rights for Northern Ireland”, DG II (2004), paras 64-5.

11 McCrudden, "Consociationalism, equality and minorities", n. 9 above, at 340. 
by the Framework Convention's Advisory Committee in September 2000. This meant that other bodies, in particular the OSCE's High Commissioner on National Minorities, played an important role in the interim period in providing guidance to states on implementing relevant international norms as well as on their potential incorporation into domestic law. ${ }^{12}$

Tom Hadden's support for the development of more integrative approaches in relation to education and housing is also well known within Northern Ireland. The Framework Convention is unusual in explicitly recognising in Article 5 the value of a state's general integration policy alongside the need "to promote the conditions necessary for persons belonging to national minorities to maintain and develop their culture, and to preserve the essential elements of their identity". ${ }^{13}$ It is also the only one of the three instruments to make specific reference to interculturalism, requiring states to "encourage a spirit of tolerance and intercultural dialogue and take effective measures to promote mutual respect and understanding and co-operation" amongst all persons on their territory, in particular in the fields of education, culture and the media (Article 6(1)). It has been observed that Articles 5 and 6(1) of the Framework Convention are amongst the least specific provisions when it comes to imposing obligations on states parties ${ }^{14}$ and that they are expressed in the characteristically vague language of the "economic, social and cultural" rights tradition. ${ }^{15}$ Yet together they suggest that voluntary assimilation and voluntary separation remain permissible policy options but that measures aimed at the integration of those belonging to national minority groups into the wider society and at the development of dialogue between groups should be encouraged.

Tom Hadden's work on the promotion of integrative approaches at the international level is perhaps less well known in Northern Ireland but is no less significant. ${ }^{16} \mathrm{He}$ submitted a number of papers on this issue at annual sessions of the UN Working Group on Minorities and it was recognised by the chair, Asbjørn Eide, that discussion of such matters was of major significance for its work in examining possible solutions to problems involving minorities. ${ }^{17}$ More recently, Tom was involved in the development of the thematic work of the Advisory Committee established under the Framework Convention on education, ${ }^{18}$ which resulted in the adoption of a Commentary on Education by the Advisory Committee on 2 March 2006. ${ }^{19}$

12 S R Ratner, "Does international law matter in preventing ethnic conflict?" (2000) 32 New York. University Journal of International Law and Politics 591, at 623-37.

13 Article 5(2) reads: "Without prejudice to measures taken in pursuance of their general integration policy, the States shall refrain from policies or practices aimed at assimilation of persons belonging to national minorities against their will and shall protect these persons from any action aimed at such assimilation."

14 G Gilbert, "Article 5" in M Weller (ed), The Rights of Minorities: A commentary on the Framework Convention for the Protection of National Minorities (Oxford: Oxford University Press 2005), p. 153, at p. 154.

15 P Keller, "Re-thinking ethnic and cultural rights in Europe" (1998) 18 Oxford Journal of Legal Studies 29, at 31.

16 On the choices between integration and separation, see "Towards a set of regional guidelines or codes of practice on the implementation of the declaration" (paper prepared by T Hadden for the 9th session of the Working Group on Minorities, 12-16 May 2003), UN Doc. E/CN.4.Sub.2.AC.5/2003/WP.1 and T Hadden, "Integration and separation: legal and political choices in implementing minority rights", in N Ghanea and A Xanthaki (eds), Minorities, Peoples and Self-Determination (Dordrecht: Martinus Nijhoff 2005), pp. 173-91.

17 E.g. Working Group on Minorities, "Report on its sixth session" (2000), UN Doc. E/CN.4/Sub.2/2000/27, paras 91-2; "Report of the Working Group on Minorities on its seventh session" (2001), UN Doc. E/CN.4/Sub.2/2001/22, para 158 and "Report of an International Seminar on Autonomist and Integrationist Approaches to Minority Protection”, Danish Centre for Human Rights, Copenhagen, 3-4 April 2002, UN Doc. E/CN.4/Sub.2/AC.5/2002/WP.1.

18 Advisory Committee on the Framework Convention for the Protection of National Minorities, 23rd meeting, 24-27 May 2005, CoE Doc. ACFC/MR(2005)003, paras 15-18.

19 CoE Doc. ACFC/25DOC(2006)002. 


\section{A critique of the Framework Convention as a tool for the promotion of minority rights}

A particularly notable feature of the Framework Convention is the limited use of rights language. This was intentional on the part of the drafters, who were clear that a deliberate choice was made "for a framework Convention which contains mostly programme-type provisions setting out objectives which the Parties undertake to pursue" rather than "directly applicable" rights. ${ }^{20}$ As well as imposing obligations on states in relation to equality and promotion of cultural identity and of mutual respect and understanding (Articles 4-6), the Framework Convention imposes positive obligations on states in relation to the use of minority languages in relations with administrative authorities (Article 10(2)) and the display of traditional local names, street names and other topographical indications (Article 11(3)) as well as in the area of education (Articles 12-14) and in relation to the creation of conditions necessary for effective participation (Article 15). Other provisions in the Framework Convention are merely adaptations of civil and political rights in the European Convention on Human Rights (ECHR), requiring states to respect individual rights and freedoms that "are particularly relevant for the protection of national minorities", 21 i.e. the rights to freedom of peaceful assembly, association, expression and thought, conscience and religion (Articles 7-9). However, there are some additional rights recognised. These relate to the use of minority languages in public and private (Article 10(1)), names and signage (Article 11), transfrontier contacts and NGO participation (Article 17), the establishment of private educational institutions (Article 13), as well as the learning of minority languages (Article 14(1)).

When it was first adopted, the Framework Convention was generally perceived as a "weak first attempt" at guaranteeing minority rights in Europe 22 with criticism focused in particular on the failure to define the term "national minority", 23 the vague formulations of many of the substantive provisions and the envisaged enforcement system. ${ }^{24}$ Although the Advisory Committee established under the Framework Convention has worked hard to compensate for these deficiencies, the same deficiencies have led to problems in responding to calls for the "incorporation" of the Framework Convention into domestic law. It is submitted that these characteristics are inextricably linked to the decision to adopt a framework convention dealing with minority issues rather than an additional minority rights protocol to the ECHR. Awareness of these deficiencies is therefore crucial to understanding the Framework Convention's limitations in the context of debates over the content of a Bill of Rights for Northern Ireland.

It is perhaps fairly unsurprising that the Council of Europe, which had toyed with the idea of a minority rights protocol to the ECHR in the past and had developed a strong reputation as Europe's "human rights watchdog", was eager to consolidate its own position

20 Explanatory Report to the Framework Convention, para. 11.

21 Ibid. para. 51.

22 G Gilbert, "The Council of Europe and minority rights" (1996) 18 Human Rights Quarterly 160, at 189.

23 According to the Explanatory Report (para. 12): "It was decided to adopt a pragmatic approach [to the definitional issue], based on the recognition that at this stage, it is impossible to arrive at a definition capable of mustering general support of all Council of Europe member States."

24 For a particularly strong critique, see G Alfredsson, "A frame for an incomplete painting: comparison of the Framework Convention for the Protection of National Minorities with International Standards and Monitoring Procedures" (2000) 7 International Journal on Minority and Group Rights 291. 
within the "new" Europe by developing its own instruments dealing with minority protection issues. 25 The Parliamentary Assembly of the Council of Europe (PACE) had long been a supporter of the idea of such a protocol and proposed special rights going beyond rights to equality and non-discrimination for national and linguistic minorities as early as $1990 .{ }^{26}$ The European Commission for Democracy through Law (or the Venice Commission, the Council of Europe's advisory body on constitutional matters) had, however, made clear its support for the idea of a European Convention for the Protection of Minorities with its own monitoring committee. ${ }^{27}$ This prompted PACE to step up its calls for action on the elaboration of an additional protocol to the ECHR ${ }^{28}$ and to instruct its own committees to prepare such a protocol as a matter of urgency. ${ }^{29}$

The adoption by PACE of Recommendation 1201(1993) on an additional protocol on the rights of national minorities to the $\mathrm{ECHR}^{30}$ was in itself a significant event, not least because of the express recognition of the right of an individual belonging to a national minority "to learn his/her mother tongue and to receive an education in his/her mother tongue at an appropriate number of schools and of state educational and training establishments, located in accordance with the geographical distribution of the minority" in Article 8 and of a right to autonomy in Article 11. Its proposal also included a definition of the term "national minority", which required residence and citizenship of the state as well as the maintenance of "long standing, firm and lasting ties with that state". These requirements were introduced in order to ensure the exclusion of migrants, who were subject to a separate and more limited protection scheme under the Council of Europe's Convention on the Legal Status of Migrant Workers. ${ }^{31}$ The citizenship requirement also had the effect of excluding many Russian speakers in the Baltic States. ${ }^{32}$

Although it was clear to members of PACE that states would show greater resistance to the idea of an additional protocol to the ECHR with judicially enforceable rights, its ultimate hope was that "the topical nature and the urgency of minority problems, and pressure of public opinion, would convince all in due course of the need for a truly binding legal instrument". 33 However, it was the view of the Venice Commission, that "flexible, diplomatic solutions applied by a non-judicial body may prove more effective in this tricky field", 34 which eventually prevailed. The Vienna Declaration, concluded after the summit meeting of the Heads of State and Government in October 1993, ${ }^{35}$ instructed the

25 A Bloed, "The OSCE and the issue of national minorities", in A Phillips and A Rosas (eds), Universal Minority Rights (Abo, Finland and London: Abo Akademi University Institute for Human Rights and Minority Rights Group International 1995), p. 113, at p. 119.

26 PACE Recommendation 1134 (1990) on the rights of minorities.

27 ECommDL, "Proposal for a European Convention for the Protection of Minorities", reproduced in (1991) 12 Human Rights Law Journal 269.

28 PACE Recommendation 1177 (1992) on the rights of minorities (4 February 1992), para. 12.

29 Order No 474 (1992) on the rights of minorities (4 February 1992), para. 4.

301 February 1993.

31 CETS No 93 (opened for signature 24 November 1977, entered into force 1 May 1983).

32 H Klebes, "Introduction, Draft Protocol on Minority Rights to the ECHR" (1993) 14 Human Rights Law Journal 140, at 142, and Rapporteur Mr Worms, "Explanatory Memorandum, Draft Protocol on Minority Rights to the ECHR" (1993) 14 Human Rights Law Journal 146, at 146.

33 Klebes, "Introduction", n. 32 above, at p. 141.

34 Opinion of the European Commission for Democracy through Law on the proposal drawn up by the Committee on Legal Affairs and Human Rights for an additional protocol to the European Convention on Human Rights concerning the rights of minorities CDL-MIN(1992)008e-restr (7 January 1993), para. 4(bb).

35 Vienna Declaration of the Heads of State and Government of the Member States of the Council of Europe on the Reform of the Control Mechanism of the ECHR, on National Minorities, and on a Plan of Action against Racism, 9 October 1993 (1993) 14 Human Rights Law Journal 373. 
Committee of Ministers "to draft with minimum delay a framework convention specifying the principles which contracting States commit themselves to respect, in order to assure the protection of national minorities" 36 and "to begin work on drafting a protocol complementing the European Convention on Human Rights, in the cultural field by provisions guaranteeing individual rights, in particular for persons belonging to national minorities". 37 The swift progress made in the drafting of the Framework Convention for the Protection of National Minorities as well as the decision to suspend work on an additional cultural protocol, which would have required the new rights to be defined "as individual rights of universal application", 38 have all been well documented, ${ }^{39}$ as has the subsequent development of the Framework Convention and the work of the associated Advisory Committee that has surpassed all initial expectations. ${ }^{40}$

In a previous article published in this journal, I examined the monitoring of developments in relation to Irish-language education in Northern Ireland under both the Framework Convention and the European Charter for Regional or Minority Languages. ${ }^{41}$ The rest of this article will focus on the role that the Framework Convention has played in the Bill of Rights process so far and will draw in particular on my experiences as legal advisor to the Culture, Identity and Language Working Group of the Northern Ireland Bill of Rights Forum from October 2007 to March 2008.

\section{The Framework Convention and its relevance to Northern Ireland}

The promotion of the Framework Convention for the Protection of National Minorities as an instrument of particular relevance to Northern Ireland appears to have been strongly influenced by discussions on the protection of human rights and constructive approaches to group accommodation and minority protection at the Dublin Peace and Reconciliation Forum in 1996 with a paper on the former produced by Tom Hadden along with Kevin Boyle and Colm Campbell and a paper on the latter prepared by Asbjørn Eide. ${ }^{42}$ Whilst it was clearly anticipated at that stage that Irish nationalists in Northern Ireland would be protected as a "national minority" by the limited minority rights guarantees provided under the Framework Convention, what was significant for Unionist politicians at the time was that this was to be done in a way that ensured respect for existing territorial integrity. ${ }^{43}$ The appeal of this stipulation to Unionists should not be underestimated. Indeed, it has even been claimed that it was at Unionist insistence that the UK ratified the Framework Convention in January 1998, just three months before the signing of the Belfast Agreement. ${ }^{44}$ However, it was later claimed that the British government ratified the

36 Vienna Declaration, n. 35 above, at 375.

37 Ibid. and "Corrigendum" (1994) 15 Human Rights Law Journal 248.

38 F Benoit-Rohmer, The Minority Question in Europe: Texts and commentary (Strasbourg: Council of Europe 1996), p. 52 .

39 One of the earliest attempts to document these developments was made by Benoit-Rohmer, ibid. pp. 36-53.

40 On its development, see M Weller (ed.), The Rights of Minorities: A commentary on the European Framework Convention for the Protection of National Minorities (Oxford: Oxford University Press 2005) and M Weller (ed.), Universal Minority Rights: A commentary on the jurisprudence of international courts and treaty bodies (Oxford: Oxford University Press 2007).

41 E Craig, "Irish-language education and the Council of Europe's minority treaties: the monitoring of developments in Northern Ireland" (2007) 58 NILQ 121.

42 Department of the Taoiseach, "Reconvening of Forum for Peace and Reconciliation" www.taoiseach.ie/index.asp?locID=478\&docID=1011 (31 March 2009).

43 Article 21. On the influence of the work of this forum on Unionists, see D Nesbitt, "How is Northern Ireland to be Governed?", speech to the McGill Summer School, 22 July 2004, www.cain.ulst.ac.uk/issues/politics/docs/uup/dn220704.htm (31 March 2009).

44 C Bell, Peace Agreements and Human Rights (Oxford: Oxford University Press 2000), p. 175. 
Framework Convention to underline its commitment to tackling "racism and xenophobia" and its consistent stance has been that its interpretation of the term "national minority" is based on the definition of a "racial group" under the Race Relations Act 1976.45 It has therefore adopted a much broader stance on the definitional issue than most European States, which have restricted the Framework Convention's scope of application to indigenous minorities. This has led to the peculiar situation whereby the Framework Convention has been used as a lobbying tool by Unionist politicians, who have repeatedly called for its incorporation into domestic law, and by the ethnic minority sector, rather than the Irish (Catholic) minority it was originally envisaged that it would protect. ${ }^{46}$

The Advisory Committee's recent opinion on the UK provides a clear indication of its acceptance of the UK's inclusive approach with specific recommendations adopted relating to the Irish language and Ulster-Scots as well as ethnic minorities and the traveller community. ${ }^{47}$ The committee has also made recommendations in relation to the further development of integrated approaches to housing and education (under Article 6) and in relation to employment monitoring (under Article 3) in Northern Ireland. This implies that relations between the two main communities are considered to come within the ambit of the Framework Convention. However, what is not clear is whether the Protestant majority can also claim the protection of the rights guaranteed therein. To some extent this is a moot point at the international level, as speakers of Ulster-Scots are clearly protected under the Framework Convention and guarantees in relation to religion go no further than the guarantees provided under the ECHR and the Human Rights Act 1998. Nevertheless, it is possible that Protestants in Northern Ireland might in the future argue that they are not able to participate effectively in cultural, social and economic life and in public affairs as required under Article 15 and that measures altering the proportions of the population of certain areas are aimed at restricting their rights and freedoms contrary to Article 16.

The initial stance of the NIHRC and of Tom Hadden, who was probably at that time the commissioner with the most expertise in the area, was that the Bill of Rights should include some specific guarantees for the two communities along the lines of the commitments made in the Belfast Agreement and that relevant provisions of the Framework Convention should be incorporated with a view to guaranteeing the rights of members of all communities. ${ }^{48}$ These included the right of individuals born in Northern Ireland "to identify themselves and be accepted as Irish or British citizens, or both, as they may so choose" and it was suggested that the Bill of Rights might also include a right to choose to be treated or not to be treated as a member of a particular community and a general right to culture, religion and language. In addition, it was envisaged that government bodies would adopt effective and appropriate measures to meet the objectives of Articles 4-6 of the Framework Convention (on equality, minority identity and tolerance). The NIHRC's 2004 Consultation Document was different in a number of respects. ${ }^{49}$ To give effect to the references to parity of esteem in the Belfast Agreement, it proposed in s. 3(2) that: "The law of Northern Ireland shall ensure just and equal treatment for the identities

45 HC Debs, 23 February 1999, c. 298. The Race Relations Act defines a racial group as “a group of persons defined by colour, race, nationality (including citizenship) or ethnic or national origins".

46 For further information on the Unionist position, see D Nesbitt, "The particular circumstances, the Ulster Unionist Party's position", paper submitted to the Northern Ireland Bill of Rights Forum (15 October 2007), pp. 3-7.

47 Advisory Committee on the Framework Convention for the Protection of National Minorities, Second Opinion on the United Kingdom, adopted on 6 June 2007, ACFC/OP/II(2007)003.

48 NIHRC, Making a Bill of Rights for Northern Ireland (Belfast: NIHRC, September 2001), s. 3.

49 NIHRC, Progressing a Bill of Rights (Belfast: NIHRC April 2004), s. 3. 
and ethos of both main communities." It also provided that: "The law of Northern Ireland shall guarantee the rights conferred on minorities, and on individual members of minorities, by the Framework Convention for the Protection of National Minorities." However, the right to choose to be treated or not to be treated as a member of a particular community was this time omitted.

The NIHRC's stance in the 2004 Consultation Document was influenced not just by the responses it had received to its initial proposals but also to comments it had received from three Council of Europe experts on certain aspects of a future Bill of Rights for Northern Ireland. ${ }^{50}$ For example, the view of the experts had been that the issue of self-identification would be best dealt with outside of the context of the Bill of Rights project ${ }^{51}$ and they also suggested that it might be appropriate to include a general clause stipulating that: "The law of Northern Ireland shall give effect to the Framework Convention for the Protection of National Minorities." 52 In relation to language rights, the view of the Council of Europe experts was that it would be sufficient to provide that: "Language rights will be protected through legislation to implement the commitments made under the Belfast (Good Friday) Agreement, the Framework Convention for the Protection of National Minorities and the European Charter for Regional or Minority Languages." 53 The experts considered that the detail could then be expanded upon in future legislation. ${ }^{54}$ However, the stance of the NIHRC in its 2004 consultation document was that certain rights for all linguistic minorities in Northern Ireland should be included as a basic minimum (for example, the right to communicate with any public body through an interpreter, translator or facilitator when necessary for the purpose of accessing information or services essential to his or her life or security and the right to be educated in and through their language where there are substantial numbers of users and sufficient demand). ${ }^{55}$ It was clearly not intended that such rights would be restricted to speakers of the indigenous languages, that is Irish, Ulster-Scots and British and Irish sign language.

\section{The Framework Convention and the work of the Northern Ireland Bill of Rights Forum ${ }^{56}$}

To some extent the establishment of the Northern Ireland Bill of Rights Forum in December 2006 was regarded as an opportunity for a fresh start with the Bill of Rights process, yet its members failed to produce agreed recommendations that could be used to inform the NIHRC advice to the government. This article does not intend to criticise the process, although a number of criticisms could be made in that regard, but rather to focus instead on the role of the Framework Convention as a "false friend" to those involved in discussions over the content of a Bill of Rights for Northern Ireland. A lot of the discussions over the Framework Convention in the forum took place within the Culture, Identity and Language Working Group, with a lot of initial enthusiasm within the working group for the principles in the Framework Convention and for the idea of its incorporation into domestic law. This clearly might have been appropriate had an additional minority rights protocol to the ECHR been adopted with the inclusion of rights that were clearly

50 Council of Europe Experts, "Comments", n. 10 above.

51 Ibid. para. 69.

52 Ibid. para. 55.

53 Ibid. para. 75 .

54 Ibid. paras 57-60, 70.

55 NIHRC, Progressing a Bill of Rights, n. 49 above, s. 14.

56 On the Bill of Rights Forum's work more generally, see www.billofrightsforum.org/index/what_we_do.htm (31 March 2009). 
intended to be justiciable. However, it will be recalled that the Framework Convention makes fairly limited use of rights language and, in fact, refers to a number of rights already protected under the ECHR. It is therefore significant that minority issues are increasingly being addressed under these and other rights provisions in the ECHR, including the education rights in Article 2 of the First Protocol. ${ }^{57}$ A more appropriate starting point might therefore have been to start with identifying relevant gaps in the ECHR, drawing as appropriate on provisions of other international instruments and domestic constitutions. For example, it has been generally recognised that a minimal minority rights guarantee in relation to the enjoyment of culture and the use of minority languages should be included using a formulation similar to that found in Article 27 of the International Covenant on Civil and Political Rights 1966 and in Article 2 of the UN Minorities' Declaration.

It was clear from the outset that any general reference to the need for the law to give effect to the Framework Convention would require a clear identification of groups coming within the scope of its protection and would require a decision to be made about whether the term "minority" or the term "community", which is used in the South African Constitution, ${ }^{58}$ is more appropriate in the context of Northern Ireland. These of course were not the only issues being addressed within this particular working group, which also discussed questions relating to education as well as looking at the controversial issue of parades. It is therefore unfortunate that insufficient time was given for proper consideration of these issues within the forum plenary. In particular, consideration could have been given to the stance of the Venice Commission in relation to Belgium, namely that

it is necessary to exclude from the scope of application of the Framework Convention those groups of persons that, although inferior in number to the rest or to other groups of the population, find themselves, de iure or de facto, in a dominant or co-dominant position

with co-dominance to be assessed not only at state but also at sub-state (that is regional and local) levels. ${ }^{59}$ This might have led to a more meaningful discussion over which communities in Northern Ireland are considered most vulnerable and in particular need of the protection of the minority rights guarantees contained therein.

Whilst international law does not appear to provide a clear answer to the question of whether the two main communities in Northern Ireland could or should be covered under the minority protection provisions of the Framework Convention, what is clear under international law is that preferential treatment for the speakers of indigenous languages and measures to promote such languages are justified. This is particularly apparent in the European Charter for Regional or Minority Languages of 1992, which in Article 1 defines regional or minority languages as languages "traditionally used within a given territory of a State by nationals of that State who form a group numerically smaller than the rest of the State's population" and which expressly excludes the languages of migrants. Meanwhile it is recognised in the Commentary to the UN Minorities' Declaration that "old" minorities

57 On minority rights jurisprudence generally under the core human rights treaties, see A Moucheboeuf (ed.), Minority Rights Jurisprudence (Strasbourg: Council of Europe 2006) and Weller (ed), Universal Minority Rights, n. 40 above. On minority education rights, see E Craig, "Accommodation of diversity in education: a human rights agenda?” (2003) 15 Child and Family Law Quarterly 279, at 281-7.

58 S. 31 reads: "Cultural, religious and linguistic communities: (1) Persons belonging to a cultural, religious or linguistic community may not be denied the right, with other members of that community (a) to enjoy their culture, practise their religion and use their language; and (b) to form, join and maintain cultural, religious and linguistic associations and other organs of civil society. (2) The rights in subsection (1) may not be exercised in a manner inconsistent with any provision of the Bill of Rights."

59 Venice Commission, "Opinion on Possible Groups to Which the Framework Convention for the Protection of National Minorities Could be Applied in Belgium” (8-9 March 2002), CoE Doc. CDL-AD (2002) 1. 
will often have stronger entitlements than the "new". ${ }^{60}$ This is also essentially the position under the Framework Convention, as some of its provisions impose obligations only in relation to areas inhabited by persons belonging to national minorities "traditionally" or "in substantial numbers" (for example, Article 10(2) on the use of minority languages in relations with administrative authorities and 14(2) on minority language education). According to the Explanatory Report to the Framework Convention: "It was considered preferable to adopt a flexible form of wording which will allow each Party's particular circumstances to be taken into account." 61

The differential treatment of indigenous and immigrant minorities has of course been subject to much philosophical debate and is generally considered to be one of the most significant aspects of Will Kymlicka's liberal theory of minority rights. ${ }^{62}$ It is also the aspect that has attracted the most criticism, in particular his assertion that immigrants have voluntarily relinquished the right to live and work in their own culture through immigration. ${ }^{63}$ Nevertheless, the argument that such a distinction should be drawn, particularly in relation to the recognition of official language or promotion-orientated rights, is one that remains attractive even to critics of his normative position. ${ }^{64}$ For example, Alan Patten has argued that "consent is not the operative normative principle in generating the immigrant/national group dichotomy" 65 but suggests instead that the "operative normative" principles should be the interests of the receiving society "in securing the conditions of a democratic society orientated around the realization of a scheme of justice" and "in maintaining their own languages, as sources of identity, pride, comfort, cultural heritage, connection with the past, and so on". 66 A proposal that would have given a stronger entitlement in relation to Irish-language education than to education in other minority languages was considered within the working group. However, even this proposal was not accepted within the forum plenary with objections expressed against the idea of any kind of hierarchy in relation to the protection of indigenous and non-indigenous languages.

\section{Conclusion}

Perhaps unsurprisingly, the NIHRC played it fairly safe in the advice it submitted to the Secretary of State on 10 December 2008, particularly in relation to language, culture and identity issues. 67 The term "minority" was preferred to the term "community", there was no inclusion of a general right to self-identification ${ }^{68}$ and it was recommended that "the

60 A Eide, "Final text of the Commentary to the Declaration on the Rights of Persons Belonging to National or Ethnic, Religious and Linguistic Minorities", UN Doc. E/CN.4/Sub.2/AC.5/2001/2, para 11. The commentary was endorsed by the UN Working Group on Minorities, "Report on its tenth session", UN Doc. E/CN.4/Sub.2/2004/29 para. 66(2)(b).

61 Para. 66.

62 He defines national minorities as "distinct and potentially self-governing societies incorporated into a larger state”. W Kymlicka, Multicultural Citizenship: A liberal theory of minority rights (Oxford: Clarendon Press 1995), p. 19; P Keller, "Justice and ethnicity" (1996) 59 Modern Law Review 903, at 911-12.

63 For an insight into the nature of some of these criticisms, see Keller, "Justice and ethnicity", n. 62 above, at 913-15; B Barry, Culture and Equality (Oxford: Polity Press 2001), pp. 217-20; and A Patten, "Who should have official language rights?" (2006) 31 Supreme Court Law Review 101, at 105-07.

64 For an early defence of this position, see H Kloss, "Language rights of immigrant groups" (1971) 5 International Migration Review 250, at 259-62.

65 Patten, "Who should have official language rights?", n. 63 above, at 114.

66 Ibid. at 110.

67 NIHRC, "A Bill of Rights for Northern Ireland: advice to the Secretary of State for Northern Ireland" (10 December 2008), pp. 41-2.

68 However, it is proposed that the people of Northern Ireland should have the right "to identify themselves and be accepted as Irish or British or both". 
right to learn to be educated in and through their minority language where there are substantial numbers of users and sufficient demand" be applied to all linguistic minorities, although there is at least a reference to the requirement for public authorities to act compatibly with the UK's obligations under the European Charter for Regional or Minority Languages in respect of Irish and Ulster-Scots. ${ }^{69}$ What is particularly notable is how few references there are in the NIHRC's advice to the Framework Convention ${ }^{70}$ with references made instead to the right to culture, language and identity and to recognition of the need for the state to develop a spirit of tolerance and dialogue under Articles 1 and 2 of the UN Minorities' Declaration and to paragraph 34 of the Copenhagen Document, which addresses minority language education issues. ${ }^{71}$ This accords with the argument presented here that the Framework Convention is not an instrument that can simply be transplanted into domestic law and that calls for its incorporation raise a number of complex issues that have not yet been adequately addressed by relevant parties and sectors in Northern Ireland. The points made by Tom Hadden and others in the context of the Bill of Rights process both about the potential tension between the right to self-identification and current equality legislation and about the scope of the Framework Convention raise important issues that it is to be hoped that civil society and politicians in Northern Ireland will be ready to address once a Bill of Rights for Northern Ireland is in place. In the meantime, it is clear from the number of recommendations made by the Framework Convention's Advisory Committee addressing the situation of a range of different groups in Northern Ireland that effective local, national and international monitoring remains crucial.

69 NIHRC, "A Bill of Rights", n. 67 above, pp. 41-2.

70 References are made in passing alongside other international instruments at ibid. pp. 101 and 105.

71 Ibid. pp. 101-2 and 104-5. 
